\title{
Professional Development of Academic Library Professionals in Kerala
}

\author{
SUSAN MATHEW K, susankarott@gmail.com \\ University Library, CUSAT \\ BABY, M.D, dr.babyjohny@gmail.com \\ School of Library \& Information Science, Rajagiri College of Social Sciences. \\ SREEREKHA PILLAI S, rekhacusat@gmail.com \\ University Library, CUSAT
}

\begin{abstract}
The paper aims to bring out the problems and prospects of the professional development opportunities of academic library professionals in the Universities in Kerala. The study is a part of research undertaken to survey the professional development activities and educational needs of library professionals in the major Universities of Kerala because of the developments in Information communication technology. The study recommends methods for improving the knowledge/skills of library professionals. The aim of the study is to evaluate the professional development activities of Library professionals and their attitude towards continuing education programmes. In order to achieve the objectives of the study a survey was conducted with the help of structured questionnaires distributed to 203 library professionals in seven major universities in Kerala, (South India) of which 185 questionnaires were returned. Results of the analysis show that majority of the professionals have pursued higher degrees in library science or IT allied courses after entering the profession, and that they have a positive attitude towards participation in training programmes and workshops. The results show that developments in ICT have a positive influence on majority of library professionals' attitude towards continuing education programmes.
\end{abstract}

Keywords: Professional development; Continuing Education Programmes (CEP); Library Professional, Kerala; Educational needs; Information Communication Technology (ICT)

\section{INTRODUCTION}

Developments in Information communication technologies (ICT) have revolutionized the information handling capabilities of academic libraries and information centres all over the world. Librarians, especially academic librarians have been facing challenges in the profession due to the rapid technological changes with the development of information technologies, particularly the Internet. Now Librarians have to play the role of mediator between the vast network of resources and its users. To meet the ever-changing demands of the users, library professional require continuously updated knowledge and skills for effective performance. Continuing education is necessary for every professional, not only in library profession but also in all service sectors and it is fundamentally a responsibility of the individual professional. A librarian's motivation for continued learning involves a mixture of social responsibility, desire for advancement, professional pride, a concern for future libraries, the need to keep abreast of new knowledge and technology, as well as an interest in supplementing professional training (ALA, 1980). Maintaining professional competence is the process by which professionals keep current the knowledge, skills, and abilities needed to function effectively in their profession (Chan \& Auster, 2003). Competence of a library depends largely on the competence of its staff. Hence, it is important to assess the library professionals' needs for continuing education and professional development in the changing electronic environment of an academic library.

\section{RELATED STUDIES}

Various studies have researched the professional development activities and continuing education needs of librarians. Majority of the studies have stressed that the organization as well as the library professional is jointly responsible for striving towards professional development. Ramaiah and Moorthy (2002) reported the need and impact of continuing education programmes (CEP) for library and information science (LIS) professionals in India, particularly for college librarians. Kannappanavar and Praveen Kumar (2005) evaluated the training 
programmes pertaining to Library and Information science and their effectiveness as stated by library professionals in selected Agricultural Science Libraries in India. Sagolsem, Purnima Devi and Vikas (2007) reported a survey conducted among the library professional staff working in public libraries and NGO libraries of Manipur. They stressed the importance of continuing education programmes to upgrade professional competencies and suggested that the government should provide more grants for library development in the state. According to Chan and Auster (2003) professional librarians are motivated to maintain their professional competence but they should be encouraged to participate in updating activities. The findings were based on studies conducted on professional development practices of reference librarians in Ontario. Their study recommended that libraries develop and implement policies that support formal and informal training. Adanu (2007) in a study of university libraries in Ghana opined that the work environment of professional librarians encouraged professional development leading to job advancement and updated skills. He also pointed out that continuing professional development (CPD) was a shared responsibility of the library and the individual.

\section{OBJECTIVES}

The aim of the study is to determine how far the library professionals have utilized the opportunities for career development. The objectives have been framed as follows:

1. To evaluate the professional development activities of Library professionals.

2. To study the attitudes of library professionals towards continuing education programmes.(CEP)

3. To recommend methods for improving the knowledge/skills of library professionals

\section{METHODOLOGY}

The study population included the qualified library professionals of the seven major Universities in the state of Kerala, which included young professionals with 3-5 years experience and professionals with 20 or more years of experience. The Universities included in the study are University of Kerala (UOK), Mahatma Gandhi University (MGU), Cochin University of science and technology (CUSAT), University of Calicut (UOC), Kannur University (KAN), Sree Sankaracharya University of Sanskrit Kaladi (SSU), and Kerala Agricultural University (KAU). All the Universities have a main central library and departmental libraries attached to the various teaching departments/schools of the University. The Library professionals covered in this study were either employed in the central libraries or in the departmental libraries in the main campuses of the universities and have acquired their undergraduate or postgraduate qualification in a formal education programme of library and information studies.

The research design for this study was the survey method using structured questionnaire and observation. The copies of the questionnaire were personally administered to the library professionals permanently employed in the universities; while a few were mailed to the respondents. Out of the total 203 questionnaires distributed 185(91.1\%) were returned. The questionnaire was meant to collect data about details of age, gender, educational qualifications, designation, experience, and information regarding the professional activities of library professionals including participation in continuing education programmes (CEP), publication trends, membership in professional associations, attitudes towards CEP etc. The data generated were analyzed by frequency count and percentage analysis using Microsoft Excel and statistical analysis using Chi-squared tests.

\section{RESULTS AND FINDINGS}

\section{General Characteristics}

The analysis of respondents showed that most of the library professionals at the time of survey fall in the age group above 36 years (37.8 percent). Only 30.3 percent of the professionals responded are below 35 years of age. The remaining 31.9 percent are above 46 years of age. Majority of the respondents (59.5 percent) are female and 40.5 percent are male. The study 
results showed that most of the library professionals are well qualified with Post Graduate Degree in Library and Information science (LIS) (Table.1). The basic qualification for entry cadre as a Library professional in state universities being Bachelor's Degree with additional Degree in Library science (BLISc), it was found that professionals having only BLISc degree are 9.2 percent, while 50.3 percent of professionals have Master's degree in LIS, 30.3 percent have MPhil degrees, and 10.2 percent have attained PhD in LIS. It was also found that 44.3 percent of the professionals have a Post Graduate degree in their basic subject and 48.1 percent are Graduates. A few of the professionals have additional degrees in Management (3.8percent), Law (2.7percent), and Journalism (.5percent) and Diploma in computer application (7.6percent).

Table 1: Qualification of Respondents

\begin{tabular}{|l|l|l|}
\hline Qualification & Frequency & Percent \\
\hline PhD & 19 & 10.2 \\
\hline MPhil & 56 & 30.3 \\
\hline MLISc & 93 & 50.3 \\
\hline BLISc & 17 & 9.2 \\
\hline Total & $\mathbf{1 8 5}$ & $\mathbf{1 0 0}$ \\
\hline
\end{tabular}

In the category of Library Professionals, while 41.6 percent belong to the junior most Professional Assistant/ Library Assistant /Technical Assistant category, 17.8 percent to middle level Junior Librarian / Reference Assistant category, 37.3 percent to Assistant Librarian category, and 3.2 percent to senior most level of Deputy Librarian. (Table.2)

Table 2: Category of Respondents

\begin{tabular}{|l|l|l|}
\hline Category & Frequency & Percent \\
\hline Deputy Librarian & 6 & 3.2 \\
\hline Assistant Librarian & 69 & 37.3 \\
\hline $\begin{array}{l}\text { Junior Librarian/ Reference Asst/ } \\
\text { Technical Asst }\end{array}$ & 33 & 17.8 \\
\hline $\begin{array}{l}\text { Professional Assistant/Library } \\
\text { Assistant }\end{array}$ & 77 & 41.6 \\
\hline Total & $\mathbf{1 8 5}$ & $\mathbf{1 0 0}$ \\
\hline
\end{tabular}

While most of the Library professionals (49.2 percent) have $5-15$ years experience, only 11.4 percent of the professionals have below 5 years experience, 31.3 percent have 16-25 years of experience and a few (8.1 percent) above 26 years of experience in library profession.(Table.3)

Table 3: Experience of Respondents

\begin{tabular}{|l|l|l|}
\hline Experience & Frequency & Percent \\
\hline Below 5 Years & 21 & 11.4 \\
\hline $5-15$ Years & 91 & 49.2 \\
\hline $16-25$ Years & 58 & 31.3 \\
\hline Above 26 Years & 15 & 8.1 \\
\hline Total & $\mathbf{1 8 5}$ & $\mathbf{1 0 0}$ \\
\hline
\end{tabular}




\section{Enrolment in Higher Education}

On analysing the enrolment in higher degrees in library and Information science (LIS) by the library professionals in all universities it was found that, 64.3 percent of professionals have pursued higher degrees after entering the profession. As shown in Table.4, 78.0 percent of professionals above 46 years have enrolled in higher education after joining the profession, whereas in the age group 36-45 it is 62.9 percent and the lowest among the younger age group (51.8 percent).

Table 4: Enrolment in Higher Degree in LIS According to Age

\begin{tabular}{|l|l|l|l|}
\hline \multirow{2}{*}{ Age } & \multicolumn{2}{|l|}{ Enrolment in higher degree } & \multirow{2}{*}{ Total } \\
\cline { 2 - 3 } & Yes & No & \\
\hline \multirow{2}{*}{$25-35$ Years } & 29 & 27 & 56 \\
& $(51.8 \%)$ & $(48.2 \%)$ & $(100.0 \%)$ \\
\hline \multirow{2}{*}{$36-45$ Years } & 44 & 26 & 70 \\
& $(62.9 \%)$ & $(37.1 \%)$ & $(100.0 \%)$ \\
\hline \multirow{2}{*}{ Above 46Years } & 46 & 13 & 59 \\
& $(78.0 \%)$ & $(22.0 \%)$ & $(100.0 \%)$ \\
\hline \multirow{2}{*}{ Total } & $\mathbf{1 1 9}$ & $\mathbf{6 6}$ & $\mathbf{1 8 5}$ \\
& $\mathbf{( 6 4 . 3 \% )}$ & $\mathbf{( 3 5 . 7 \% )}$ & $\mathbf{( 1 0 0 . 0 \% )}$ \\
\hline
\end{tabular}

Among the professionals having the highest degree i.e. $\mathrm{PhD}, 84.2$ percent have pursued higher education and 75 percent of Mphil holders have joined higher courses, while MISc and BLISc degree holders have comparatively lesser rate of enrolment i.e. 59.1 percent and 35.3 percent respectively. It was found that majority of BLISc degree holders (64.7 percent) have not pursued any higher education.

Majority of library professionals in the category of Deputy Librarian (66.7 percent), and 79.7percent of Assistant Librarians have enrolled for higher education at some stage in their career. Whereas in in the case of Junior Librarian (or Reference Assistant), it is 57.6 percent and Professional Assistants (or Technical Assistant) 53.2percent. Computation of Chi-square values indicated that enrolment in higher degree is associated with Age, Qualification and Category of professionals.

Of the total professionals, 35.7 percent indicated that they have not enrolled for any higher degree. The reasons quoted were not interested (48.5 percent), not allowed by the university (6.1percent), and there is no need for a higher degree in the present post (45.5 percent). A few also pointed out that financial constraints prevented them from pursuing higher degrees. Analysis of different IT or computer related degrees acquired by Library professionals found that 23.8 percent professionals have completed computer related degree or diploma in the course of their career and a few indicated that they already had the degree before entering the profession. Only a few (3.8 percent) have degree in Management studies which shows that ICT has influenced the professionals in pursuing higher education in Computer related courses.

\section{Publication Trends}

The publication pattern of library professionals was appraised by analysing the number of publications in journals, books and conference proceedings. As seen in Figure.1 majority of library professionals (79.5 percent) have no publications indicating the poor trend in publishing papers. 17.3 percent of the library staff have journal articles/ articles in books/conference papers etc, and a very few (1.6 percent) have more publications 5 to 10 or more than 10 publications each. It was also found that professionals having higher qualifications like Post graduation and Doctorate have more publication than the less qualified professionals. The dependency of age, gender, experience and qualification on publication pattern was calculated using Chi-square test. Significant values of Chi-square were found for qualification, which proved that qualification has a distinct relation to the publication pattern of library professionals. 


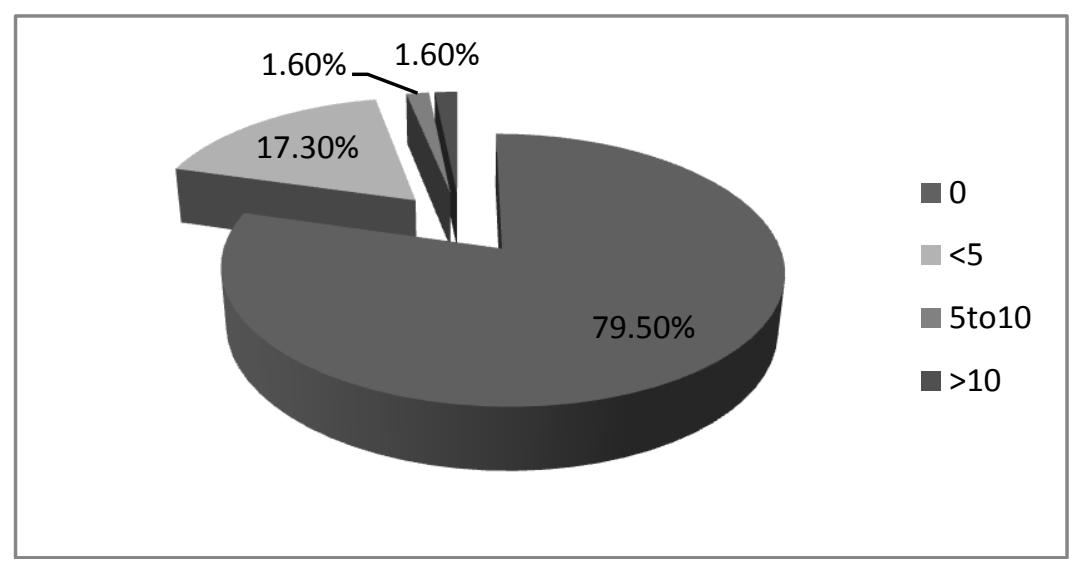

Figure 1: Publication Trends of Library Professionals

\section{Membership in Professional Associations}

Professional associations have a major role in supporting and raising awareness in professional development at the national level and within the profession and providing opportunities to gain practical skill through active participation in professional activities. Library professionals' membership in local, national and international associations was analysed as a part of the evaluation of their professional activities. It was found that 69.2 percent of the library professionals have membership in one or two library associations. None have membership in Library associations at the International level. National level associations like Indian Association of Special Libraries and Information centres, IASLIC (3.1 percent) and Indian Library Association, ILA (7.3 percent) have very few members from the Universities of Kerala and Society for Advancement of Library and Information Science, SALIS has 1.7 percent members. Among the total professionals who have membership, 92.2 percent were members of Kerala Library Association, KLA and 28.1 percent in Kerala Library Professionals Organisation, KELPRO. University wise analysis of membership in professional associations is depicted in the Fig. 2 below. It is clear that majority of the professionals of KAU, SSU, KAN and other Universities are members of KLA and KELPRO.

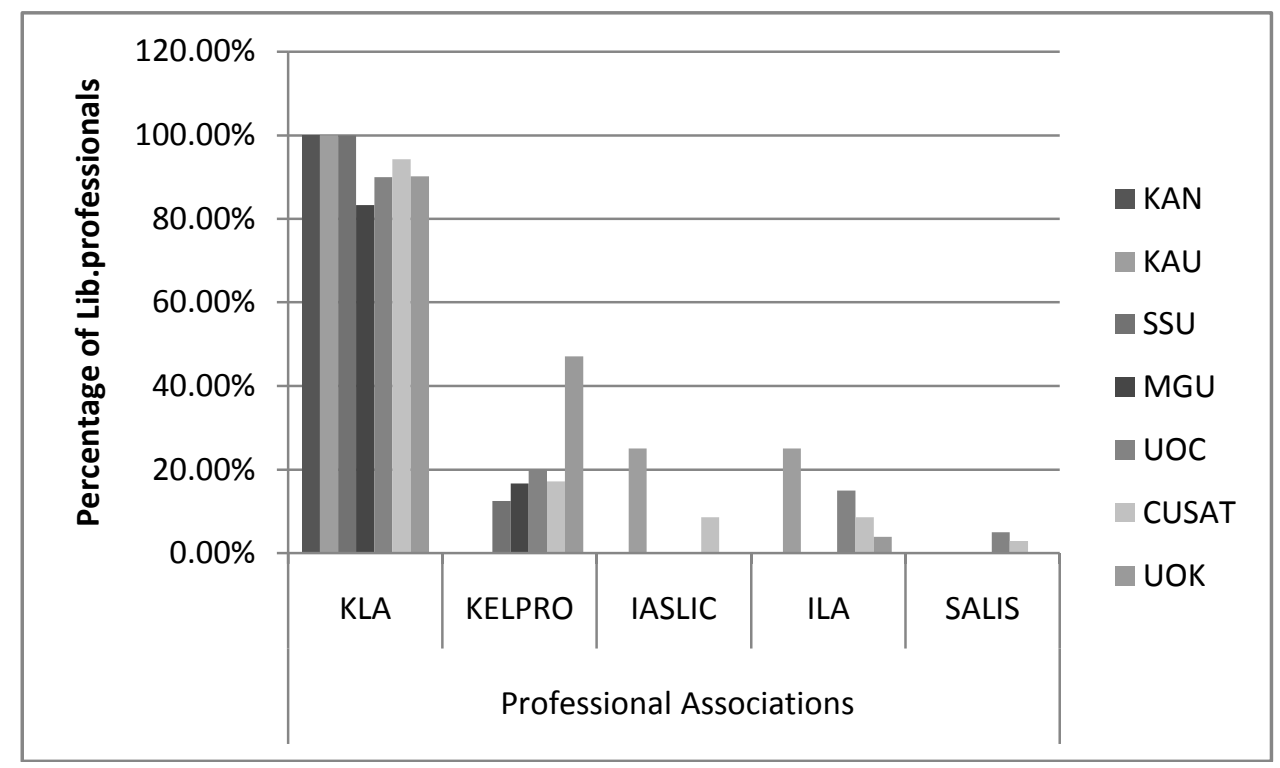

Figure 2: Membership in Professional Associations 


\section{Attendance in Continuing Education Programmes (CEP)}

The participation of Library professionals in Continuing Education Programmes including Conferences, Workshops, Refresher courses, In-house training programmes etc is depicted in Table.5. In the Universities in Kerala, library professionals' participation in continuing education programmes is usually based on seniority and it also depends on sponsorship from the parent institution. Opportunities for career development is limited to very few senior professionals who have attained UGC(University Grants Commission) prescribed qualifications and have been inducted in the UGC scale of pay. The prospects of improving skills depend much on the interests of the professionals as there is hardly any encouragement from the higher authorities. The analysis shows that participation is more in In-house training conducted by Universities (52.4 percent), followed by Workshops sponsored (41.6 percent) and not sponsored (34.6 percent), Conferences not sponsored (33.5 percent) and least attendance in sponsored Conferences(29.7 percent) and Refresher courses(23.8 percent) which is mandatory for professionals in the UGC stream. It is evident that library professionals have better participation in the training programmes and workshops conducted by each University, than the sponsored programmes.

It was found that 40 percent male respondents and 33.2 percent females have attended the Continuing Education Programmes. Attendance in CEP is comparatively more in the age group 36-45 and above 46 years. It was also seen that Library professionals with highest qualification, viz. PhD and MLISc have better average of participation in Conferences, Workshops and training programmes than other qualified professionals. Professional Assistant/ Technical Assistant category have the least participation in CEP especially in refresher courses in which their participation is only 2.6 percent, reasonable participation in-house training programmes (44.2percent), whereas the Assistant Librarian category has a comparatively better attendance in all programmes. Library professionals in the category of Deputy Librarian have high participation in refresher courses (83.3 percent) and fair average of attendance in conferences (33.3 percent), and sponsored workshops (50 percent). Junior Librarian category has reasonable attendance in all programmes except refresher courses (12.1percent). Refresher courses being mandatory for career development, only the senior professionals attend it for acquiring higher grades. Analysis of participation in CEP according to experience found that professionals having experience between 16 to 25 years have participated in more professional development programmes than the other group of professionals.

Table.5 Attendance in Continuing Education Programmes (CEP)

\begin{tabular}{|l|l|l|l|}
\hline Continuing Education Programme & Attended & Not Attended & Total \\
\hline Conference (Institution Sponsored) & 55 & 130 & 185 \\
& $(29.7 \%)$ & $(70.3 \%)$ & $(100 \%)$ \\
\hline Conference(Not Sponsored) & 62 & 123 & 185 \\
& $(33.5 \%)$ & $(66.5 \%)$ & $(100 \%)$ \\
\hline \multirow{2}{*}{ Workshop (Institution Sponsored) } & 77 & 108 & 185 \\
& $(41.6 \%)$ & $(58.4 \%)$ & $(100 \%)$ \\
\hline \multirow{2}{*}{ Workshop(Not Sponsored) } & 64 & 121 & 185 \\
& $(34.6 \%)$ & $(65.4 \%)$ & $(100 \%)$ \\
\hline Refresher Courses & 44 & 141 & 185 \\
& $(23.8 \%)$ & $(76.2 \%)$ & $(100 \%)$ \\
\hline In-houseTraining Programmes & 97 & 88 & 185 \\
& $(52.4 \%)$ & $(47.6 \%)$ & $(100 \%)$ \\
\hline
\end{tabular}

\section{Attitude towards Continuing Education Programmes (CEP)}

The Library professionals were asked to indicate their attitude towards Continuing Education Programmes (CEP) and the results are shown in the Fig 3. It was found that 72 percent of the library professionals attend CEP to get trained in the latest technologies and 60.5 percent to acquire new skills, which show developments in ICT, has a positive influence on majority of library professional's participation in professional development programmes. 53.5 percent of the 
professionals indicated that they attend CEP to update knowledge or basic education while 53 percent pointed out that they attend CEP to improve library services.

Training junior staff was indicated as one reason to participate in CEP by 8.6 percent of library professionals. 27 percent professionals pointed out that CEP are necessary to improve relation with fellow professionals. Attending CEP is important for promotion to higher grade especially to professionals who have UGC scale of pay, which was the opinion of 9.2 percent of library professionals. Ramaiah and Moorthy (2002) in a survey of participants in continuing education programmes had similar findings and pointed out that majority of professionals attended CEP to improve basic knowledge/skills and improve library services.

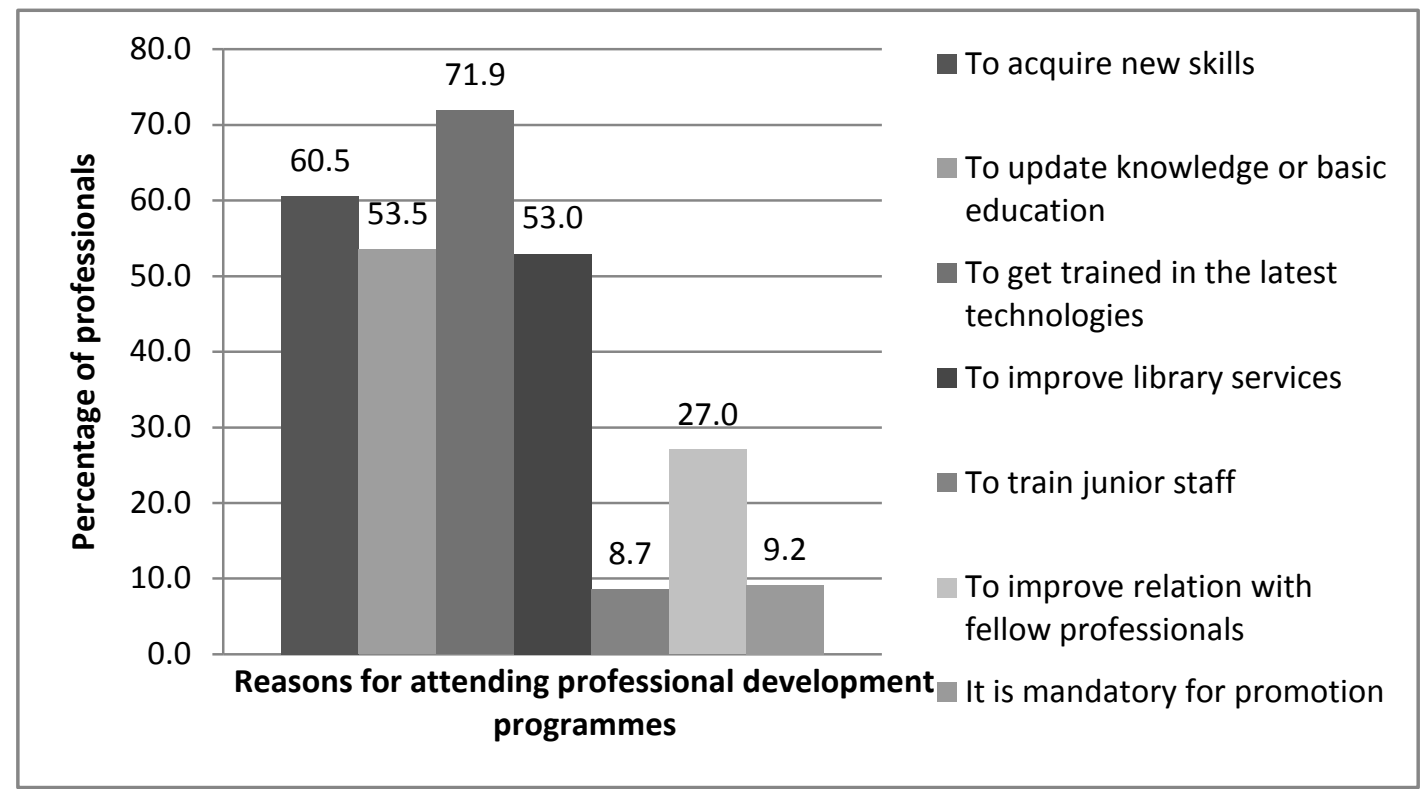

Figure 3: Reasons for Attending Continuing Education Programmes

Analysis of the reasons for not preferring continuing education revealed very few responses indicating that majority of the library professionals are in favour of continuing education programmes. As evident from Table.6, one of the reasons pointed out by library professionals was that CEP were restricted to a particular grade only(6percent), while very few(0.5 percent) were of the opinion that CEP do not influence their professional work. Financial constraints were also one reason pointed out by library professionals for not participating in any such programmes. Very few 4.9 percent of the library professionals were not at all interested to attend any CEP. Adomi \& Nwalo (2003) noted in their study that LIS professionals and paraprofessionals desire to update their skills and knowledge through continuing professional development (CPD), but some constraints, such as lack of IT components for practice/work, lack of self and organizational motivation, financial constraints, amongst others, restrict the staff from taking advantage of professional development programmes.

Table 6: Reasons for Not Attending CEP

\begin{tabular}{|l|l|}
\hline Reasons for Not Attending CEP & Frequency \\
\hline Restricted to a Particular grade & $11(6 \%)$ \\
\hline Do not Influence Professional Work & $1(0.5 \%)$ \\
\hline Financial Constraints & $1(0.5 \%)$ \\
\hline Not Interested & $9(4.9 \%)$ \\
\hline
\end{tabular}

The results of analysis of library professionals' opinion to know whether the Continuing education programmes have any effect on updating skills are shown in Table 7. Majority of the professionals were of opinion that CEP has helped to update skills to some extent (55.1 
percent). Around 33 percent were of opinion that CEP has helped to update their skills to a great extent, very few even noted that CEP has not at all helped to update their skills (1.1 percent) and 10.8 percent failed to give any response. Library professionals in different age groups with different qualifying degrees, and all categories had similar opinion that CEP has helped in updating skills.

Table 7: Effect of CEP on Updating Skills

\begin{tabular}{|l|l|}
\hline CEP Has Helped To Update Skills & Frequency \\
\hline To Some Extent & $102(55.1 \%)$ \\
\hline To a Great Extent & $61(33.0 \%)$ \\
\hline Not at all & $2(1.1 \%)$ \\
\hline No response & $20(10.8 \%)$ \\
\hline Total & $185(100.0 \%)$ \\
\hline
\end{tabular}

\section{Suggestions for Updating Skills}

Library professionals were asked to give their suggestions for updating the skills and knowledge important for the profession. Majority of Library professionals expressed the necessity of conducting training programmes and workshops by their respective institutions and pointed out that participation in such programmes is important for updating skills. Other suggestions included searching Internet for online resources or relevant professional information, regularly reading relevant professional literature and also general books, regular attendance of relevant conferences/workshops, professional association meetings, undertaking research projects/publications etc. Discussion of professional matters with colleagues was also one important suggestion provided by library professionals.

\section{CONCLUSION AND RECOMMENDATIONS}

From the analysis of professional developmental activities like enrolment in higher education, publication pattern, membership in professional associations and participation in continuing education programmes, it is evident that some of the personal characteristics like age, qualification, experience ,category etc influence library professionals in their professional activities. The experienced professionals have pursued higher degrees in the course of their career. The trend in publishing research articles was found to be poor among the professionals but those with higher qualifications had better average of publications. Chan and Auster (2003) have also made similar observations in their study that individual characteristics are significant factors in participation in updating activities. Membership in professional associations illustrate that majority of the professionals was aware of the importance of professional association in career development. The analysis found that majority of the library professionals have a positive approach to continuing education programmes and that they participate in these programmes to get trained in the latest technologies and acquire new skills. Analysis of the opinion about continuing education programmes prove that participation in such programmes has helped to update their skills to some extent.

At the entry level, a basic degree with degree in library science is the required qualification for a library professional in the state universities. In the changing electronic environment, higher qualification especially in information technology related areas is to be made mandatory for serving the IT perceptive academic community. The facilities like study leave and other incentives provided to teaching faculty must be extended to library professionals also, to encourage them to acquire higher qualifications. As refresher courses and career advancement is mandatory for professionals in the UGC cadre only, the professionals in the junior and middle level are mostly not sponsored by the Universities to attend such programmes. Professionals for whom the attendance is mandatory for attaining senior grades mostly attend the conferences and workshops. The number of professionals who have attended such training programmes purely for attaining knowledge may be very few. A continuous 
programme of professional development must be compulsory for all library professionals. The training programmes and orientation programmes to develop skills of library professionals are to be organized by the institution in a regular manner and equal opportunities are to be provided to all library professionals irrespective of experience/category to participate in workshops/seminars etc conducted by various other institutions and library associations. Professional development activities ought to be encouraged from the junior most level to develop the competencies of all professionals in providing various technology based services.

The Library science departments and the professional associations have to take the initiatives to organize on a regular basis, continuing education programmes to ensure that the working professionals are competent to face the challenges of the profession. The library science curriculum in most of the universities has to be restructured by incorporating the emerging changes in libraries and according to the changing needs of the user community. In addition to the basic qualification and requirements for a career in library and information science, library professionals on their part, have to continuously update their skills to maintain and support user centered applications and face the challenges of ever increasing demands for wide-ranging IT oriented services from the academic community. The university administrators have to encourage and sponsor the professionals for participating in continuing education programmes, for which most of the professionals have a positive attitude, but issues like financial constraints and fewer promotional prospects deter them from striving towards professional development.

\section{REFERENCES}

Adanu, T. S. (2007). Continuing Professional Development (CPD) In State-Owned University Libraries In Ghana. Library Management, 28(6/7), 292-305.

Adomi, E. E., \& Nwalo, K. I. (2003). Prospects for continuing professional education for library and information science professionals in Nigeria: The Case Of Delta State . New Library World, 104(1194/1195), 499-508.

ALA. (1980). In-Service Training. In ALA World Encyclopedia Of Library And Information Services (P. 601). Chicago: American Library Association.

Chan, D. C., \& Auster, E. (2003). Factors contributing to the professional development of reference librarians. Library \& Information Science Research, 25, 265-286.

Kannappanavar, B. U., \& Praveen Kumar, K. (2005). Effectiveness and usefulness of training programmes for library professionals in India: Survey Of The Library Professionals Working In Agricultural Science University Libraries. ILA Bulletin, 41(4), 18-22.

Ramaiah, C. K., \& Moorthy, A. L. (2002). The impact of continuing education programmes on library and information science professionals. Library Review, 51(1), 24-31.

Sagolsem, M., Purnima Devi, T., \& Vikas, T. (2007). Professional development in digital environment: a case study of public libraries in manipur. In M. Kumar (Ed.), International CALIBER 2007: Information And Knowlege Management In Networked World (pp. 570578). Chandigarh: Inflibnet Centre. 